\title{
The Impact of Adduction of Folding Paper Stages for Children's Fine Motor Skills
}

\author{
Sri Widayati, Nurhenti Dorlina Simatupang, Puput Puspita Sari \\ Department of Early Childhood Teacher Education \\ Universitas Negeri Surabaya \\ Surabaya, Indonesia \\ sriwidayati@unesa.ac.id
}

\begin{abstract}
The purpose of this study is to illustrate the impact of giving folding stages to the subtle motoric abilities of children, especially in folding paper. The sample in this study was 15 children. Data collection techniques used observation, interviews, and documentation. The research observation sheet includes measuring the ability to fold a child, 3 namely: 1 ) the child is able to connect the a to $b$ side symmetrically correctly, 2 ) the child is able to connect a side to b quickly and press it firmly, 3) the child is able to make the fold neat with symmetrical folds. Data analysis techniques use the interactive model Miles and Huberman. From the results of the research carried out giving stages of paper folding greatly impacted on the fine motor skills of children, especially in folding. In general, children become more able to do origami folding activities independently without teacher guidance.
\end{abstract}

\section{Keywords—stages of paper folding; fine motor skills}

\section{INTRODUCTION}

Early childhood especially those aged 3-5 years are the most critical period [1]. At that age the child's brain development develops up to $50 \%$. While the age of $6-8$ years of development reaches $30 \%$, so the age of children 3-8 years must be maximally stimulated by educators, both teachers and parents [2].

At the age of 3-8 years old children fall into school. Parents can entrust their children to school institutions to assist and educate their children in accordance with the growth and development of children is one of the institutions that serve children aged 4-7 years in Indonesia.

Kindergarten is early childhood education on the path of formal education which aims to help students develop a variety of potential both psychological and physical which includes moral and religious values, social emotional, independence, cognitive, language, physical / motoric and art to be ready to enter elementary school [3]. General Kindergarten aims to provide stimulation or stimulation for the development of children's potential to become human believers and fear God Almighty, noble, healthy, knowledgeable, capable, creative, innovative, independent, confident and to be democratic and responsible citizens [4].

The aspects of early childhood development are religious and moral, cognitive, physical motoric, language, social emotional and stimulated arts in kindergarten. One of the most stimulated aspects in kindergarten or era is the fine motor aspect. Fine motoric is a movement that involves the fingers of the fingers of the muscles needed for tasks such as writing, drawing and so on [5]. One activity that can improve fine motor is paper folding. Folding activities in early childhood is one of the life skill (skills), especially training children's fine motor skills [6].

The basic observation in Kindergarten implemented the activity of folding the paper before the child was given origami folding activities. This study aims to look at the impact of giving stages of folding activities on children's fine motor skills, especially in folding activities.

The problem of this research is how the impact of giving activities to the stages of folding paper on children motor skills at Kindergarten ". Objective in this research is to determine the impact of the stages of folding the paper in fine motoric children. The benefits of this research are 1) for the institution, this research expected to be an evaluation as an effort to improve the quality of learning 2) for teachers, this study can be used as an evaluation in order to form learning activities continue of innovation in accordance with the stages of child development an early age, and 3) for further research are that this research expected to broaden knowledge and can be used as a reference

The purpose of folding activities is to train the child's ability to fold mirror / mirror neatly and develop children's visual spatial abilities [5]. Besides folding paper also has benefits including a) the formation of more perfect motor skills in both hands, b) increased intellectual ability, c) increased creative power abilities; d) improve the ability to focus attention (concentration), e) improve memory skills (memory), and f) exercise patience [7]. Paper folding activities aim to train eye and hand muscle coordination and concentration.

In addition, folding activities require eye coordination, hand skills and visual spatial abilities [8]. To teach folding activities in kindergartens, folding steps need to be mastered by the teacher [9]. The first thing that must be mastered by children is the child's ability to fold the base. The basic fold is meant to fold 1 to stage 5 [6]. 
When describing folds, state the place where the folds start and end, or other marks [10]. Orient the sample in the same way as children when folding activities. Treat each step as one unit: First identify the position and orientation of the current model, take steps, and then confirm the new position. Make sure each child has done this step correctly before proceeding to the next step. If the child feels difficulty, then the steps to fold must be repeated. Try to find a clearer explanation. If a step is challenging, ask the children to hold their paper to examine the entire class at the same time. Encourage them to help each other.

General paper folding activities are generally in kindergarten associated with origami activities. Therefore, the need for this research is done to describe the impact of giving folding stages before the teacher gives origami folding activities to the child [11].

\section{METHODS}

The type of research used in this study is descriptive qualitative research because in this study only reveals the facts then explains descriptively about a related matter. This research was conducted in 2018. Researchers took data in group A at the kindergarten. The sample of this study was the group A children at the kindergarten which has total of 30 children. Data retrieval is carried out five times the folding activities using paper. The first informant was the class teacher. The second informant was the child of group A himself. In addition, the researcher prepared an observation sheet related to the ability of children to fold paper and documentation in the form of photographs. The stages of research are as follows:

1). In the preparation phase, at this stage the researcher prepares an observation sheet for the subtle motoric abilities of the child regarding folding activities, namely: a) the child is able to connect the sides a to b symmetrically correctly, b) the child is able to connect sides a to b quickly and press strong and c) the child is able to make the neat folds by forming symmetrical folds. In addition, at the preparation stage the researcher coordinates with the schedule for implementing the folding stage activities. The schedule and activities of folding stages are as follows; a) the teacher gives activity of folding paper as much as a crease, namely making umbrellas, b) the teachers provide activities folding the paper as much as twofold, namely making the trunk c) the teacher gives the activity of folding paper three folds, namely making ice cream cones, d) teacher gives paper folding activities four folds, namely making a hat, e) the teacher gives a folding paper.

2). During the implementation phase, at this stage the researcher carries out his research in accordance with the planned stages and schedules.

$3)$. The evaluation phase, at this stage the researcher wants to triangulation data on all data obtained from the beginning of the study until the end of the study. To get a research conclusion.

Instrument observation sheet of subtle motoric abilities of children in folding activities. Data collection techniques used by researchers are interviews, observation, and documentation.
Observations were made by observing the results in the form of field notes and observation sheets for the subtle motoric abilities of children when folding activities. Documentation is carried out in the form of photos which are then narrated and coded. Teacher and child interviews as additional information for triangulating data.

Data analysis in descriptive qualitative research uses the interactive models of Miles and Huberman.

\section{RESUlTS AND Discussion}

The results obtained from observations of researchers from the folding stage activities obtained the following data:

1) The first stage (one fold, make an umbrella)

To clarify Table 1 the results of stage I can be seen in graphical form as follows:

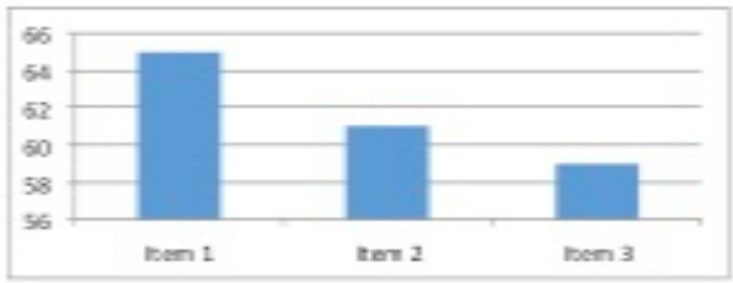

Fig. 1. Results of first phase data Ability to Fold Children in Group A

Based on the graph for item 3, the results of neat folds with symmetrical folds are still low. In the implementation of stage I all children can do folds because only children fold one-fold only.

2) Second stage (twice fold, making tree trunks)

Activity from stage two obtained data as table 2 below:

TABLE I. RECAPITUlation OF SECOND PHASE RESUlt

\begin{tabular}{|c|c|c|c|}
\hline \multirow{2}{*}{ Score } & \multicolumn{3}{|c|}{ Item } \\
\cline { 2 - 4 } & 1 & 2 & 3 \\
\hline 1 & & 1 child & 3 child \\
\hline 2 & 19 child & 17 child & 20 child \\
\hline 3 & 11 child & 12 child & 7 child \\
\hline 4 & 0 child & 0 child & 0 child \\
\hline
\end{tabular}

To clarify Table 1 the results of stage I can be seen in graphical form as follows:

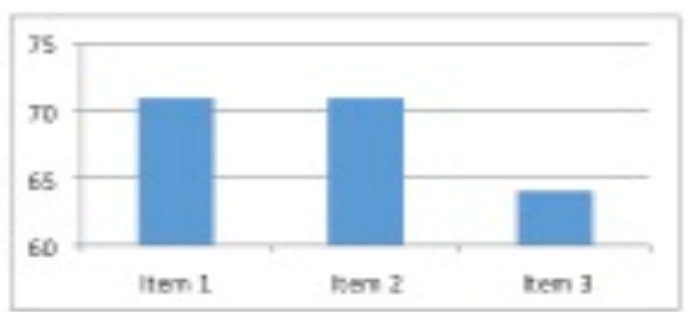

Fig. 2. Results Data stage 2 Ability to Fold Children in Group A 
Based on the graph above in item 2 which is connecting the side $a$ to $b$ quickly and pressing it strongly has increased. In the implementation of stages II there is an increase in the child's ability to fold.

3) Third stage (three folds, make ice cream cone)

The third stage of the data is obtained as follows: Table 2 below:

TABLE II. RECAPItUlation of Phase 3 Results

\begin{tabular}{|c|c|c|c|}
\hline \multirow{2}{*}{ Score } & \multicolumn{3}{|c|}{ Item } \\
\cline { 2 - 4 } & $\mathbf{1}$ & $\mathbf{2}$ & $\mathbf{3}$ \\
\hline 1 & 0 child & 0 child & 0 child \\
\hline 2 & 4 child & 7 child & 19 child \\
\hline 3 & 26 child & 23 child & 11 child \\
\hline 4 & 0 child & 0 child & 0 child \\
\hline
\end{tabular}

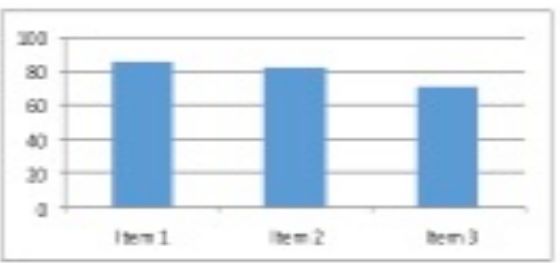

Fig. 3. Stage 3 Results Ability to Fold Children in Group A

Based on the above graph in items 1 to item 3 there is no score of 1 , this indicates that the ability of children to fold has increased.

4) Fourth Stage (four folds, making a hat) below:

The activity of fourth stages all obtained data as table 4

TABLE III. ReCAPItUlation OF Phase 4 Result

\begin{tabular}{|c|c|c|c|}
\hline \multirow{2}{*}{ Score } & \multicolumn{3}{|c|}{ Item } \\
\cline { 2 - 4 } & $\mathbf{1}$ & $\mathbf{2}$ & $\mathbf{3}$ \\
\hline 1 & 0 child & 0 child & 7 child \\
\hline 2 & 0 child & 4 child & 20 child \\
\hline 3 & 26 child & 26 child & 3 child \\
\hline 4 & 4 child & 0 child & 0 child \\
\hline
\end{tabular}

To clarify Table 3 the results of stage 4 can be seen in graphical form as follows:

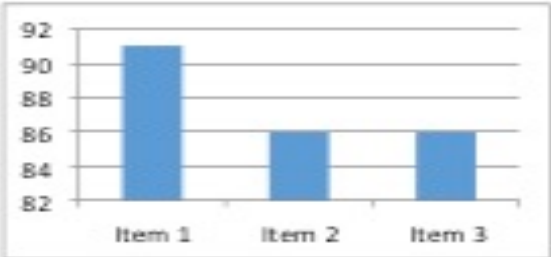

Fig.4. Results of stage 4 data Ability to Fold Children in Group A
Based on the graph above, items 1 and 2 experienced an increase, especially item 1 where there were children who got a score of 4 . Meanwhile, for item 3 it decreased.

5) Fifth stage (five folds, make the head of the car)

Data on the fifth stage is obtained as follows:

\section{TABLE IV. ReCAPitUlation OF Phase 5 Results}

\begin{tabular}{|c|c|c|c|}
\hline \multirow{2}{*}{ Score } & \multicolumn{3}{|c|}{ Item } \\
\cline { 2 - 4 } & $\mathbf{1}$ & $\mathbf{2}$ & $\mathbf{3}$ \\
\hline 1 & 0 child & 0 child & 0 child \\
\hline 2 & 1 child & 6 child & 1 child \\
\hline 3 & 23 child & 22 child & 25 child \\
\hline 4 & 6 child & 2 child & 4 child \\
\hline
\end{tabular}

To clarify Table 4 the results of stage 5 can be seen in graphical form as follows:

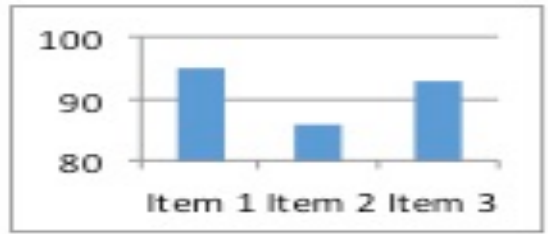

Fig.5. Results of stage 5 data Ability to Fold Children in Group A

The ability of children on all items has increased and all items have children who have scored 4.

Based on the data described above, the data table 6 is obtained as follows:

TABLE V. Recapitulation of Stages 1-5 DATA

\begin{tabular}{|c|c|c|c|c|c|c|c|}
\hline \multirow{2}{*}{ No } & \multirow{2}{*}{ Stages } & \multirow[t]{2}{*}{ Indikator } & \multicolumn{4}{|c|}{ Score } & \multirow{2}{*}{ Jumlah } \\
\hline & & & $B B$ & $M B$ & $B S H$ & $B S B$ & \\
\hline \multirow[t]{3}{*}{1} & \multirow{3}{*}{$\begin{array}{c}\text { Stages } \\
I\end{array}$} & Item 1 & 2 & 21 & 7 & & 30 \\
\hline & & Item 2 & 5 & 19 & 6 & & 30 \\
\hline & & Item 3 & 5 & 21 & 4 & & 30 \\
\hline \multirow[t]{3}{*}{2} & \multirow{3}{*}{$\begin{array}{c}\text { Stages } \\
I I\end{array}$} & Item 1 & & 19 & 11 & & 30 \\
\hline & & Item 2 & 1 & 17 & 12 & & 30 \\
\hline & & Item 3 & 3 & 20 & 7 & & 30 \\
\hline \multirow[t]{3}{*}{3} & \multirow{3}{*}{$\begin{array}{l}\text { Stages } \\
\text { III }\end{array}$} & Item 1 & & 4 & 26 & & 30 \\
\hline & & Item 2 & & 7 & 23 & & 30 \\
\hline & & Item 3 & & 19 & 11 & & 30 \\
\hline \multirow[t]{3}{*}{4} & \multirow{3}{*}{$\begin{array}{l}\text { Stages } \\
\text { IV }\end{array}$} & Item 1 & & & 26 & 4 & 30 \\
\hline & & Item 2 & & 4 & 26 & & 30 \\
\hline & & Item 3 & & 7 & 20 & 3 & 30 \\
\hline \multirow[t]{3}{*}{5} & \multirow{3}{*}{$\begin{array}{c}\text { Stages } \\
V\end{array}$} & Item 1 & & 1 & 23 & 6 & 30 \\
\hline & & Item 2 & & 6 & 22 & 2 & 30 \\
\hline & & Item 3 & & 1 & 25 & 4 & 30 \\
\hline
\end{tabular}

Information:

Item 1 : Connecting the sides a to b symmetrically with right 
Item 2 : Connect side a to b quickly and pressing it firmly Item 3 : The result of folds is neat by forming a fold symmetrical

To clarify Table 6 can be seen in the following graphical form:

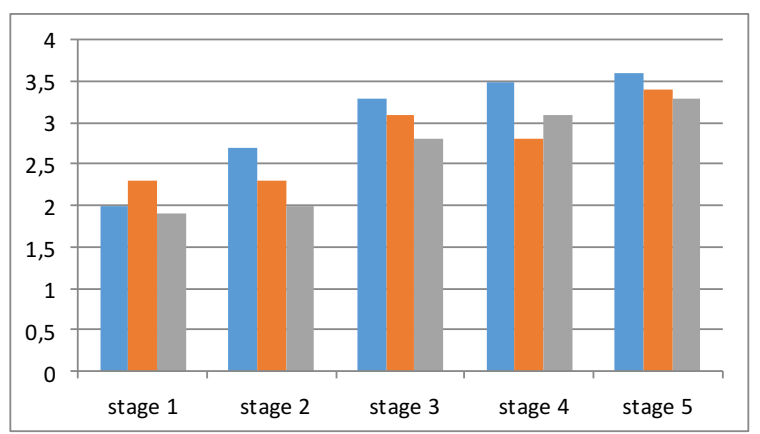

Fig.6. Fine motoric abilities of children through folding stages

Based on the graph, it can be seen that the fine motor skills at Roudhotul Athfal have increased starting from stage 1 to stage five. Folding paper is a great way to help children work fine motor skills and how to guide children to processes such as writing, sorting, and counting [12]. When describing folds, specify the place where folds start and end, or other signs. Orient the sample in the same way as children when folding activities [10]. Treat each step as one unit: First identify the position and orientation of the current model, take steps, and then confirm the new position. Make sure each child has done this step correctly before proceeding to the next step [13]. If the child feels difficulty, then the steps to fold must be repeated. Try to find a clearer explanation. If a step is challenging, ask the children to hold their paper to examine the entire class at the same time. Encourage them to help each other.

\section{CONCLUSION}

Based on the research results that the impact of the activities of the stages of folding are the fine motor skills of children increased from every stage. This is evidenced by the data in table 6 and graph 6 which show the ability of the child to experience improvement from each stage carried out.

\section{REFERENCES}

[1] Iii, C. A. N., Zeanah, C. H., \& Fox, N. A. (2019). Review Article How Early Experience Shapes Human Development: The Case of Psychosocial Deprivation. 2019.

[2] Bloock, S. (n.d.). Penerapan Aspek Perkembangan Anak Usia Dini Dalam Media Macca. 95-104.

[3] Undang-Undang Nomor 20 Tahun 2003 tentang Sistem Pendidika Nasional Kementerian Pendidikan Dan Kebudayaan. 2014. Peraturan Menteri Pendidikan dan Kebudayaan Republik Indonesia Nomor 137 Tahun 2014 tentang Standar Nasional Pendidikan Child Usia Dini. Jakarta: Mendikbud.

[4] Suyadi. 2014. Teori Pembelajaran Child Usia Dini Dalam Kajian Neurosains. Bandung: PT Remaja Rosdakarya

[5] Essa, Eva L. 2003. Introduction To Early Childhood Education. Canada: Thomson.

[6] Widayati, Sri. 2014. Panduan Dasar Melipat Kertas. Yogyakarta: Gava Media

[7] Pratiwi, Oktariani Nurul. "Predicting student placement class using data mining." Proceedings of 2013 IEEE International Conference on Teaching, Assessment and Learning for Engineering (TALE). IEEE, 2013.

[8] Siburian, Herpita. 2016. Penerapan Kegiatan Melipat Terhadap Kemampuan Motorik Halus Child Usia 5-6 Tahun Di TK ST. Antonius 2. Jurnal Handayani. Vol. 6 No. 1: 99-108

[9] Akayuure, P., Alebna, V., Investigating, V., Akayuure, P., \& Alebna, V. (2016). Investigating the Effect of Origami Instruction on Pre- service Teachers 'Spatial Ability and Geometric Knowledge for Teaching To cite this article: Investigating the Effect of Origami Instruction on Preservice Teachers' Spatial Ability and Geometric K.

[10] Pearl, Barbara. 2016. Origami In The Classroom, (Online, acessed 11 April 2018)

[11] Aeni, Qurrotul. 2016. Pengaruh Kegiatan Origami Terhadap Keterampilan Motorik Halus Pada Child Kelompok B TK Muslimat NU 128 Ass'adah Bejan Siwalan Panceng Gresik. Skripsi tidak diterbitkan. Surabaya: Universitas Negeri Surabaya.

[12] Stewart, J Deborah. 2010. Folding Paper In Preschool, (Online, acessed 15 Maret 2018)

[13] Tenbrink, T., \& Taylor, H. A. (2015). Conceptual transformation and cognitive processes in Origami paper folding. In Journal of Problem Solving (Vol. 8, pp. 2-22). 